\title{
Maternal and fetal outcomes of obese pregnant women: a prospective cohort study
}

\author{
Jenniferbritto John ${ }^{1 *}$, Mary Mahendran²
}

\begin{abstract}
${ }^{1}$ Department of Obstetrics and Gynecology, Chettinad Hospital and Research Institute, Kelambakkam, Chennai. Tamil Nadu, India

${ }^{2}$ Department of Obstetrics and Gynecology, CSI Rainy Multispecialty Hospital, Old washermanpet, Chennai, Tamil $\mathrm{Nadu}$
\end{abstract}

Received: 17 November 2016

Accepted: 13 December 2016

\section{*Correspondence:}

Dr. Jenniferbritto John,

E-mail: drjenni12345@gmail.com

Copyright: ( ) the author(s), publisher and licensee Medip Academy. This is an open-access article distributed under the terms of the Creative Commons Attribution Non-Commercial License, which permits unrestricted non-commercial use, distribution, and reproduction in any medium, provided the original work is properly cited.

\begin{abstract}
Background: Obesity in Indian women had increased from $10.6 \%$ to $14.8 \%$ in India. Mothers who are overweight or obese during pregnancy and childbirth cause significant antenatal, intrapartum, postpartum and also neonatal complications. The present study aimed to explore various maternal and fetal outcomes influenced by maternal obesity. The objective was to find the effect of obesity on maternal and perinatal outcome among obese pregnant women compared to those of normal weight.

Methods: The study was conducted in antenatal women attending antenatal outpatient department of CSI rainy multispecialty hospital located in North Chennai of South India. Consecutive sampling method was followed to include 50 cases and 50 controls. Analysis was done with IBM SPSS v.21.0. Chi square test was applied to find difference between proportions. For comparison of means independent t-test and ANOVA was applied. Pearson's correlation was done to find association between maternal BMI and birth weight.

Results: Sixteen (32\%) cases developed gestational diabetes mellitus during their antenatal period and 19 (38\%) developed gestational hypertension. $10 \%$ underwent in emergency caesarean section and in $28 \%$ cases elective caesarean section was done. The proportion of cases who developed ante partum complications including gestational diabetes mellitus, gestational hypertension and preeclampsia were higher than in control groups $(\mathrm{p}$ value $=$ $0.03,0.00,0.004$ respectively). The need for induction of labour and caesarean section was found to be higher in cases than in controls $(\mathrm{p}=0.014,0.03$ respectively). Increased NICU admissions for stabilization of the newborn among cases was higher than control group $(\mathrm{p}=0.012)$.

Conclusions: It was clearly evident from the present study that maternal obesity had adverse maternal and fetal outcomes. Maternal obesity was strongly associated with antenatal complications like gestational diabetes mellitus, gestational hypertension, preeclampsia and increase in need for induction of labour and operative interference.
\end{abstract}

Keywords: Fetal outcome, Maternal outcome, Obese women

\section{INTRODUCTION}

India is facing dual burden of nutrition of under nutrition and escalating rise in overweight and obesity problem. India has more than 30 million obese people and the number is increasing alarmingly. ${ }^{1-3}$ Many studies indicated that there is rising prevalence of overweight and obesity amongst children of all ages is increasing in the past few decades. ${ }^{4}$ Mothers who are overweight or obese during pregnancy and childbirth, as measured by increasing maternal body mass index (BMI), are known to be at risk of significant antenatal, intrapartum, postpartum and also neonatal complications. Diabetes, hypertensive disorders including preeclampsia, fetal 
deaths, big sized babies, postdate pregnancies, caesarean sections have all been associated with maternal obesity. . $^{-8}$ Overweight and obese women are more likely to be induced and require a caesarean section for delivery. ${ }^{9-10}$ There appears to be a dose-dependent relationship between maternal obesity and fetal macrosomia. ${ }^{11}$ In addition, still births and increased mortality of babies in postnatal and perinatal period are found in obese pregnant women. ${ }^{12}$ The present study aimed to explore various maternal and fetal outcomes, influenced by maternal obesity. The objective of the study was to find the effect of obesity on maternal and perinatal outcome in obese women compared to those of normal weight women.

\section{METHODS}

The study was conducted in a multispecialty hospital CSI Rainy Multispecialty Hospital located in North Chennai of Tamil Nadu, India. Prospective cohort study was designed. The Cohort was the antenatal women who were registered in their first trimester during January to March 2014. The study population constituted of antenatal women of 50 cases and 50 controls attending antenatal outpatient department of CSI Rainy Multispecialty Hospital. The study population fulfilling inclusion criteria willing to participate were included in the study.

Inclusion criteria included- antenatal women who were in first trimester with $\mathrm{BMI} \geq 30 \mathrm{~kg} / \mathrm{m}^{2}$ regardless age and parity, who were willing to participate in the study. Antenatal women who were not booked at first trimester, those with previous miscarriages and anomaly babies and those with BMI $<30 \mathrm{~kg} / \mathrm{m}^{2}$ were excluded from the study. Controls were antenatal women who were in first trimester with BMI between $25.1 \mathrm{~kg} / \mathrm{m}^{2}$ and $29.9 \mathrm{~kg} / \mathrm{m}^{2}$.

Hundred antenatal women with fifty in each of the two groups were included. The formula for $\mathrm{z}$ tests for proportions was used with $G$ power software version 3.0.10 for calculating sample size. From previous records of the hospital acquired from Medical Records Department, fetal outcome - macrosomia (in percentages) were obtained. The difference between two independent proportions with case $(29.7 \%)$ and controls (10\%) was used for sample size calculation. With alpha significance of 0.05 and $80 \%$ power of the study, the total sample size to be included for the study was 124 . However, the number of women who could be recruited with the study period was 100 (50 cases and 50 controls).

The study period was from January 2014 to May 2015. Sampling method Consecutive sampling method as the study was conducted in outpatient department of hospital.

A standardized questionnaire was used and details pertaining to socioeconomic status according to $\mathrm{BG}$ Prasad's scale 13, Medical history, clinical examination, maternal history during antenatal, partum and post partum period and of the delivered baby were collected . For measuring weight, a standardised bathroom scale was used. For measuring height stadiometer was used. BMI was calculated using the formula weight (in $\mathrm{kg}$ )/ height $\left(\mathrm{m}^{2}\right)$. The criteria used for BMI is ACOG BMI 14 classification of maternal weight and optimal weight gain during pregnancy: $\geq 30$ - obese, 25 to 29.9 overweight, 18 to 24.9 - normal and $<17.9$ - underweight. During antenatal period, development of gestational diabetes mellitus, gestational hypertension, pre-eclampsia, malpresentation, abruption placenta and placenta previa were observed. Labour induction and their indication, mode of delivery (vaginal/caesarean delivery), shoulder dystocia and instrumental delivery detailed were collected. Development of any complication in post partum period-deep vein thrombosis, postoperative wound infection, postoperative wound dehiscence and duration of hospital stay. Neonatal outcomes were gestational age at birth, birth weight (in $\mathrm{kg}$ ), admission in neonatal intensive care unit (NICU) and indications for admission. The study participants were followed up to delivery and postpartum period till they get discharged from the hospital.

Data analysis was done with statistical package for social sciences (SPSS IBM) version 21.0. The qualitative variables are described in the form of proportions and quantitative variables are described in the terms of mean, median, range and standard deviation. Data was checked for normality before applying appropriate tests of significance. Significance of difference in proportions (qualitative variables) was calculated using chi square test. Significance of $p$ value was taken as $p<0.05$. Significance difference in means was calculated using independent t-test and ANOVA. Two groups were compared for the antepartum, intrapartum complication and neonatal outcomes. Correlation between two quantitative variables - BMI and maternal weight with neonatal birth weight and amniotic fluid index was calculated with Pearson's correlation coefficient and scatter diagram.

Ethical permission was obtained from Institutional Ethical Committee before conducting the study.

\section{RESULTS}

The age of cases-obese study participants ranged from 21 years - 35 years with mean $(S D)$ of $29.5( \pm 2.9)$. Among the controls the age range is $20-33$ years with mean(SD) of $28( \pm 2.9)$. Majority of the study participants- cases $(68 \%)$ and controls (84\%) belong to Class IV and Class V socioeconomic class (Table 1). Among the study participants, the proportion of cases (obese participants) who developed antepartum complications like gestational diabetes mellitus, gestational hypertension and preeclampsia were higher than in control groups ( $\mathrm{p}$ value $=$ 0.03,0.00,0.004 respectively). Intrapartum complications like need for induction of labour, operative interference especially emergency caesarean section were found to be 
higher in cases. During the postpartum period, requirement of NICU admission for delivered baby was higher in mothers who had childhood obesity history ( $\mathrm{p}=$ 0.010) (Table 3). Estimated fetal weight and amniotic fluid index was higher among cases when compared to controls (Table 4).

Table 1: Profile of the study participants $(\mathrm{N}=100)$.

\begin{tabular}{|c|c|c|}
\hline Profile & $\begin{array}{l}\text { Cases }(\mathbf{n}=\mathbf{5 0}) \\
\mathbf{N}(\%)\end{array}$ & $\begin{array}{l}\text { Control }(\mathbf{n}=\mathbf{5 0}) \\
\mathbf{N}(\%)\end{array}$ \\
\hline \multicolumn{3}{|c|}{ Age group (in years) } \\
\hline $\begin{array}{l}20-24 \\
25-30 \\
31-35 \\
>35\end{array}$ & $\begin{array}{l}2(4) \\
29(58) \\
19(38) \\
0\end{array}$ & $\begin{array}{l}7(14) \\
32(64) \\
11(22) \\
0\end{array}$ \\
\hline \multicolumn{3}{|l|}{ Occupation } \\
\hline $\begin{array}{l}\text { Housewife } \\
\text { Skilled worker } \\
\text { Unskilled worker } \\
\text { Clerk } \\
\text { Semi } \\
\text { Professional }\end{array}$ & $\begin{array}{l}42(84) \\
4(8) \\
2(4) \\
1(2) \\
1(2)\end{array}$ & $\begin{array}{l}46(92) \\
2(4) \\
1(2) \\
1(2) \\
0\end{array}$ \\
\hline \multicolumn{3}{|c|}{ Socio-economic status* } \\
\hline $\begin{array}{l}\text { Class I } \\
\text { Class II } \\
\text { Class III } \\
\text { Class IV } \\
\text { Class V }\end{array}$ & $\begin{array}{l}0 \\
1(2) \\
15(30) \\
18(36) \\
16(32)\end{array}$ & $\begin{array}{l}0 \\
0 \\
8(16) \\
19(38) \\
23(46)\end{array}$ \\
\hline \multicolumn{3}{|l|}{ Gravida } \\
\hline $\begin{array}{l}\text { Primipara } \\
\text { Multipara }\left(2^{\text {nd }}\right. \\
\text { Gravida) } \\
\text { Multipara ( } 3^{\text {rd }} \\
\text { Gravida) } \\
\text { Multipara ( } 4^{\text {th }} \\
\text { Gravida) }\end{array}$ & $\begin{array}{l}18(36) \\
18(36) \\
10(20) \\
4(8)\end{array}$ & $\begin{array}{l}23(46) \\
11(22) \\
13(26) \\
3(6)\end{array}$ \\
\hline \multicolumn{3}{|l|}{ Parity } \\
\hline $\begin{array}{l}\text { Zero } \\
\text { One } \\
\text { Two } \\
\text { Three }\end{array}$ & $\begin{array}{l}19(38) \\
23(46) \\
6(12) \\
2(4)\end{array}$ & $\begin{array}{l}23(46) \\
16(32) \\
10(20) \\
1(2)\end{array}$ \\
\hline \multicolumn{3}{|l|}{ Previous abortion } \\
\hline $\begin{array}{l}\text { Yes } \\
\text { No }\end{array}$ & $\begin{array}{l}9(18) \\
41(82)\end{array}$ & $\begin{array}{l}42(84) \\
8(16)\end{array}$ \\
\hline \multicolumn{3}{|l|}{ Childhood obesity } \\
\hline $\begin{array}{l}\text { yes } \\
\text { no }\end{array}$ & $\begin{array}{l}13(26) \\
37(74)\end{array}$ & $\begin{array}{l}17(34) \\
33(66)\end{array}$ \\
\hline
\end{tabular}

\section{Correlation between BMI and other parameters}

Pearson correlation test was applied to find correlation of BMI with neonatal birth weight, amniotic fluid index and estimated fetal weight by ultrasound. Maternal BMI was positively correlated with neonatal birth weight $(\mathrm{r}=+0.81)$ and estimated fetal weight $(\mathrm{r}=+0.10)$.
Correlation between maternal BMI and amniotic fluid index is weakly positive $(\mathrm{r}=0.025)$.

Table 2: Vital parameters of the study population $(n=100)$.

\begin{tabular}{|l|l|l|}
\hline Vital signs & $\begin{array}{l}\text { Cases } \\
\text { Mean (SD) } \\
\text { n }=50\end{array}$ & $\begin{array}{l}\text { Controls } \\
\text { Mean }(\text { SD }) \\
\text { n }=50\end{array}$ \\
\hline Height $(\mathrm{cm})$ & $158( \pm 5.2)$ & $159( \pm 5.7)$ \\
\hline Weight $(\mathrm{kg})$ & $88( \pm 7)$ & $60( \pm 3.9)$ \\
\hline BMI $\left(\mathrm{kg} / \mathrm{m}^{2}\right)$ & $35( \pm 3.3)$ & $23( \pm 1.6)$ \\
\hline Pulse rate (per min) & $84( \pm 7)$ & $81( \pm 7.2)$ \\
\hline $\begin{array}{l}\text { Systolic blood } \\
\text { pressure (per } \mathrm{mmHg})\end{array}$ & $120( \pm 20)$ & $107( \pm 13)$ \\
\hline $\begin{array}{l}\text { Diastolic blood } \\
\text { pressure (per mmHg) }\end{array}$ & $80( \pm 10)$ & $70( \pm 9)$ \\
\hline
\end{tabular}

\section{DISCUSSION}

In the present study, association between maternal obesity and gestational diabetes mellitus was found to be statistically significant $(\mathrm{p}=0.03$ ). In a study done by Uebe $\mathrm{K}$ et al and Abenhaim HA et al similar increased risk of gestational diabetes mellitus. ${ }^{15,16}$

Table 3: Association of maternal obesity with antepartum complications and neonatal outcomes. (N=100).

\begin{tabular}{|c|c|c|c|}
\hline Outcomes & $\begin{array}{l}\text { Cases } \\
\text { N }(\%)\end{array}$ & $\begin{array}{l}\text { Controls } \\
\text { N }(\%)\end{array}$ & p value \\
\hline \multicolumn{4}{|c|}{ Antepartum complication } \\
\hline \multicolumn{4}{|c|}{ Gestational diabetes mellitus } \\
\hline Yes & $16(32)$ & $4(8)$ & \\
\hline No & $34(68)$ & $46(92)$ & 0.03 \\
\hline \multicolumn{4}{|c|}{ Gestational hypertension } \\
\hline $\begin{array}{l}\text { Yes } \\
\text { No }\end{array}$ & $\begin{array}{l}19(38) \\
31(62)\end{array}$ & $\begin{array}{l}4(8) \\
46(92)\end{array}$ & 0.00 \\
\hline $\begin{array}{l}\text { Precclampsia } \\
\text { Yes } \\
\text { No }\end{array}$ & $\begin{array}{l}12(24) \\
38(76)\end{array}$ & $\begin{array}{l}2(4) \\
48(96)\end{array}$ & 0.004 \\
\hline \multicolumn{4}{|c|}{ Need for induction of labour } \\
\hline $\begin{array}{l}\text { Yes } \\
\text { No }\end{array}$ & $\begin{array}{l}10(20) \\
40(80)\end{array}$ & $\begin{array}{l}2(4) \\
48(96)\end{array}$ & 0.014 \\
\hline \multicolumn{4}{|c|}{ Mode of delivery } \\
\hline $\begin{array}{l}\text { Vaginal } \\
\text { Caeserean } \\
\text { section }\end{array}$ & $\begin{array}{l}31(62) \\
19(38)\end{array}$ & $\begin{array}{l}44(88) \\
6(12)\end{array}$ & 0.03 \\
\hline \multicolumn{4}{|c|}{ Post partum complications } \\
\hline \multicolumn{4}{|c|}{ Postpartum fever } \\
\hline $\begin{array}{l}\text { Yes } \\
\text { No }\end{array}$ & $\begin{array}{l}3(6) \\
47(94)\end{array}$ & $\begin{array}{l}0 \\
50(100)\end{array}$ & - \\
\hline \multicolumn{4}{|c|}{ Wound infection } \\
\hline $\begin{array}{l}\text { Yes } \\
\text { No }\end{array}$ & $\begin{array}{l}3(6) \\
47(94)\end{array}$ & $\begin{array}{l}0 \\
50(100)\end{array}$ & - \\
\hline
\end{tabular}

Chi square test applied, $\mathrm{p}$ value $<0.05$ is significant 
The proportion of cases who developed gestational hypertension and pre-eclampsia were higher than in control groups ( $\mathrm{p}$ value $=0.00,0.004$ respectively). Similar association between maternal obesity and pregnancy induced hypertension has been made clearly in many studies. ${ }^{17-23}$

The incidence of still birth was $10 \%$ (5) and IUD was $2 \%$ (1) among the cases which was higher than controls. Previous studies have reported similar findings. ${ }^{24-26}$ In the present study, the need for induction of labour among cases was higher $(20 \%)$. This finding has been reported already. ${ }^{22}$ There was a higher proportion of cases landed up in caesarean section when compared to the controls (38\% vs $12 \%$ ). Other studies have reported increased incidence of caesarean section among obese mothers.18,20,24,27,28 The indications for caesarean section were failed induction (4\%), macrosomia (18\%) and prolonged labour $(6 \%)$. Similar findings of prolonged labour was reported in previous studies. ${ }^{21,29-31}$

Table 4: Association between maternal obesity and other variables $(\mathrm{N}=100)$.

\begin{tabular}{|c|c|c|c|c|c|}
\hline Variables & Mean (SD) & T value & Mean difference & $95 \% \mathrm{CI}$ & p value \\
\hline \multicolumn{6}{|c|}{ Estimated fetal weight } \\
\hline $\begin{array}{l}\text { Case } \\
\text { Control }\end{array}$ & $\begin{array}{l}3.43( \pm 0.51) \\
2.90( \pm 0.30)\end{array}$ & 6.341 & 0.536 & $0.368-0.703$ & 0.000 \\
\hline \multicolumn{6}{|c|}{ Amniotic fluid index } \\
\hline $\begin{array}{l}\text { Case } \\
\text { Control }\end{array}$ & $\begin{array}{l}12.68( \pm 3.0) \\
10.28( \pm 2.2)\end{array}$ & 4.569 & 2.406 & $1.361-3.450$ & 0.000 \\
\hline \multicolumn{6}{|c|}{ Neonatal birth weight } \\
\hline $\begin{array}{l}\text { Case } \\
\text { Control }\end{array}$ & $\begin{array}{l}3.21( \pm 0.86) \\
2.9( \pm 0.28)\end{array}$ & 1.815 & 0.233 & $-0.021-0.488$ & 0.073 \\
\hline \multicolumn{6}{|c|}{ Neonatal gestational age } \\
\hline $\begin{array}{l}\text { Case } \\
\text { Control }\end{array}$ & $\begin{array}{l}37.46( \pm 2.9) \\
38.4( \pm 4.2)\end{array}$ & -1.012 & 78.960 & $-233.77-75.854$ & 0.314 \\
\hline
\end{tabular}

Independent $\mathrm{t}$ test applied, $\mathrm{p}$ value $<0.05$ is significant.

The mean (SD) birth weight was found to be higher in cases when compared to controls $(3.2( \pm 0.86)$ vs 2.9 $( \pm 0.28))(\mathrm{p}=0.07)$. Other studies have found out similar higher incidence of macrosomia. ${ }^{28,31-34}$ In the present study it was found that increased NICU admissions for stabilisation of the newborn of cases was found when compared to the control group $(22 \%$ vs $10 \%)(p=0.012)$. Majority of this admission (12\% of $22 \%$ ) was due to fetal distress. It was clearly evident that maternal obesity had lead to fetal distress and subsequent admission to NICU. Other studies have also reported similar findings of increased NICU admissions for babies born to obese mothers. ${ }^{33,34}$

\section{CONCLUSION}

It was clearly evident from the present study that maternal obesity had adverse maternal and fetal outcomes. Maternal obesity was strongly associated with antenatal complications like gestational diabetes mellitus, gestational hypertension and preeclampsia. Increase in need for induction of labour and increased operative interference was associated with maternal obesity. Maternal obesity was also associated with increased amniotic fluid index, big sized babies and postpartum complications like wound infection and postpartum fever. Higher NICU admissions due to fetal distress was also noted among the babies of obese women. Further exploration of other areas including neurodevelopmental outcome and future offspring obesity etc., need to be done to understand complete clinical course of maternal obesity on pregnancy and offspring. As there is higher chances of operative interference during labour, better antenatal care and prior planning for elective caesarean section could prevent complications arising out of emergency caesarean section.

\section{Funding: No funding sources}

Conflict of interest: None declared

Ethical approval: The study was approved by the Institutional Ethics Committee

\section{REFERENCES}

1. International institute for population sciences. national family health survey (NFHS-2). 1998-99: 2000;438.

2. International institute for population sciences. national family health survey (NFHS-3) 2005-06: In dia VII. Mumbai: International Institute for Population Sciences. 2007:168.

3. International institute for population sciences. National family health survey (NFHS-3) 2005-06: India. VI. Mumbai: International Institute for Population Sciences. 2007:540.

4. Reilly JJ, Dorosty AR. Epidemic of obesity in UK children. Lancet. 1999;354:1874-5. 
5. Riz AM, Laraia B. The implications of maternal overweight and obesity on the course of pregnancy and birth outcomes. Matern Child Health J. 2006;10(5):1536.

6. Andreasen KR, Andersen ML, Schantz AL. Obesity and pregnancy. Acta Obstet Gynecol Scand. 2004;83(11):1022-9.

7. Guelinckx I, Devlieger R, Beckers K, Vansant G. Maternal obesity: pregnancy complications, gestational weight gain and nutrition. Obes Rev. 2008;9(2):140-50.

8. Heslehurst N, Simpson H, Ells LJ, Rankin J, Wilkinson $\mathrm{J}$, Lang R, et al. The impact of maternal BMI status on pregnancy outcomes with immediate short-term obstetric resource implications: a meta-analysis. Obes Rev. 2008;9(6):635-83.

9. Doherty DA, Magann EF, Francis J, Morrison JC, Newnham JP. Prepregnancy body mass index and pregnancy outcomes. Int J Gynae Obst. 2006;95(3):2427.

10. Callaway LK, Prins JB, Chang AM, McIntyre HD:The prevalence and impact of overweight and obesity in an Australian obstetric population. Med J Australia. 2006;184(2):56-9.

11. Ehrenberg H, Mercer B, Catalano P. The influence of obesity and diabetes on the prevalence of macrosomia. Am J Obstet Gynecol. 2004;191:964-8.

12. Papachatzi E, Papadopoulos V, Dimitriou G, Paparrodopoulos S, Olivgeris PM, Vantarakis A. Prepregnancy maternal obesity and fetal-perinatal death in a Mediterranean country. J Perinat Med. 2015;43(3):291-8.

13. Sharma R. Revision of Prasad's social classification and provision of an online tool for real-time updating. South Asian J Cancer. 2013;2(3):157.

14. Weight gain during pregnancy. Committee opinion. American College Obstetrician and Gynecologists. Obstet Gynecol. 2013;121:210-2.

15. Uebel K, Pusch K, Gedrich K, Schneider KM, Hauner $\mathrm{H}$, Bader BL. Effect of maternal obesity with and without gestational diabetes on offspring subcutaneous and preperitoneal adipose tissue development from birth up to year-1. BMC Pregnancy and Childbirth. 2014; $14: 138$

16. Abenhaim HA, Kinch RA, Morin L, Benjamin A, Usher R. Effect of pre-pregnancy body mass index categories on obstetrical and neonatal outcomes. Gynecology and Obstetrics. 2003;21(1):24-8.

17. Mandal D, Manda S, Rakshi A, Dey RP, Biswas SC, Banerjee A. Maternal obesity and pregnancy outcome: a prospective analysis. J Assoc Physicians India. 2011;59:486-9.

18. Sahu MT, Agarwal A, Das V, Pandey A. Impact of maternal body mass index on obstetric outcome. J Obst Gyn Res. 2007;33(5):655-9.

19. Catalano PM, Mcintyre HD, Cruickshank JK, Mccance DR, Dyer AR. The hyperglycemia and adverse pregnancy outcome study. Diabetes Care. 2012;35:780-6.

20. Athukorala C, Rumbold AR, Willson KJ, Caroline AC. The risk of adverse pregnancy outcomes in women who are overweight or obese. BMC Pregnancy and Childbirth. 2010;10:56.

21. Feresu SA, Wang Y, Dickinson S. Relationship between maternal obesity and prenatal, metabolic syndrome, obstetrical and perinatal complications of pregnancy in India, 2008-2010. BMC Pregnancy and Childbirth. 2015;15:266.

22. Ahmed SR, Ellah MAA, Mohamed OA, Eid HM. Prepregnancy obesity and pregnancy outcome. Int $\mathrm{J}$ Health Sci. 2000;3(2).

23. Abenhaim HA, Kinch RA, Morin L, Benjamin A, Usher R. Effect of pre-pregnancy body mass index categories on obstetrical and neonatal outcomes. Gynecology and Obstetrics. 2003;21(1):24-8.

24. Denison F, Price J, Graham C, Wild S, Liston W. Maternal obesity, length of gestation, risk of postdates pregnancy and spontaneous onset of labour at term. BJOG. 2008;115:720-5.

25. Chen A, Feresu SA, Fernandez C, Rogan WJ. Maternal obesity and the risk of infant death. United States Epidemiology. 2009;20(1):74-81.

26. Bellver J, Rossal LP, Bosch E, Zuniga A, Corona J T, Melendez F, et al. Obesity and the risk of spontaneous abortion after oocyte donation. Fertility Sterility. 2003;79(5):38-46.

27. Perlow JH, Morgan MA. Massive maternal obesity and perioperative cesarean morbidity. Am J Obstet Gynecol. 1994;170(2):560-5.

28. Abenhaim HA, Kinch RA, Morin L, Benjamin A, Usher R. Effect of pre-pregnancy body mass index categories on obstetrical and neonatal outcomes. Gynec Obst.2003;21(1):24-8.

29. Meshari AA, Silva S, Rahman I. Fetal macrosomia maternal risks and fetal outcome. Int J Gynecology Obst. 1990;32(3):215-22.

30. Ng SK, Cameron CM, Hills AP, Mcclure RJ, Scuffham PA. Socioeconomic disparities in prepregnancy BMI and impact on maternal and neonatal outcomes and postpartum weight retention: the EFHL longitudinal birth cohort study. BMC Pregnancy Childbirth. 2014;14:314.

31. Ahmed SR, Ellah MAA, Mohamed OA, Eid HM. Prepregnancy obesity and pregnancy outcome. Int $\mathrm{J}$ Health Sci. 2000;3(2):15-9.

32. Morgan KL, Rahman MA, Hill RA, Zhou SM, Bijlsma $\mathrm{G}$, et al. Physical activity and excess weight in pregnancy have independent and uniqueeffects on delivery and perinatal outcomes. PLoS One. 2014;9(4):94532.

33. Vinturache AE, Mcdonald S, Slater D, Tough S. Perinatal outcomes of maternal overweight and obesity in term infants: a population-based cohort study in Canada. Sci Rep. 2015;5:9334.

34. Kiran TS, Hemmadi S, Bethel J, Evans J. Outcome of pregnancy in a woman with an increased body mass index. BJOG Int J Obstet Gynaec. 2005;112:768-70.

Cite this article as: John J, Mahendran M. Maternal and fetal outcomes of obese pregnant women: a prospective cohort study. Int J Reprod Contracept Obstet Gynecol 2017;6:725-9. 